\title{
Penelitian Retrospektif Pasien Skabies Berdasarkan Faktor Usia dan Jenis Kelamin di Poliklinik RS Pertamina Bintang Amin Periode 2 Januari 2016-31 Desember 2018
}

\author{
Retno Oktavia ${ }^{1}$, Arif Effendi ${ }^{2}$, Eka Silvia ${ }^{3}$ \\ ${ }^{1)}$ Fakultas Kedokteran Universitas Malahayati, retnookta2610@gmail.com \\ ${ }^{2)}$ Departemen Kulit dan Kelamin Fakultas Kedokteran Universitas Malahayati, arif.effendi62@yahoo.com \\ ${ }^{3}$ Departemen Kesehatan Masyarakat Fakultas Kedokteran Universitas Malahayati, \\ waemeofficial@gmail.com
}

\begin{abstract}
ABSTRAK
Skabies adalah penyakit kulit yang disebabkan oleh infestasi dan sensitisasi terhadap Sarcoptes scabiei var hominis. Skabies ditandai dengan gatal malam hari, mengenai sekelompok orang, dengan tempat predileksi di lipatan kulit yang tipis, hangat, dan lembab. Gejala klinis dapat ditandai dengan munculnya polimorfi yang tersebar diseluruh tubuh. Adapun penyakit skabies ini dapat dicegah dengan melakukan edukasi pada pasien tentang penyakit scabies yang meliputi: perjalanan penyakit, penularan, cara eradikasi tungau skabies, menjaga higiene pribadi, dan tata cara pengobatan yang tepat. Tujuan dari penelitian ini adalah untuk mengetahui prevalensi angka kejadian skabies dan faktor-faktor yang mempengaruhi kejadian skabies berdasarkan faktor usia dan jenis kelamin di RS Pertamina Bintang Amin Periode 02 Januari 2016-31 Desember 2018. Jenis penelitian yang digunakan dalam penelitian ini adalah jenis penelitian studi retrospektif deskriptif dengan melihat catatan medik pasien skabies di Poliklinik Penyakit Kulit Dan Kelamin RS Pertamina Bintang Amin Bandar Lampung Periode 02 Januari 2016-31 Desember 2018. Pada penelitian ini didapatkan hasil prevalensi penyakit skabies yaitu sebanyak 261 kasus (9\%) dari 2924 pasien penyakit kulit dan kelamin periode 02 Januari 2016-31 Desember 2018 dengan prevalensi tertinggi yaitu pada tahun 2018 sebanyak 108 kasus (11\%) dari 963 pasien penyakit kulit dan kelamin. skabies bisa terjadi pada perempuan atau laki-laki dan anak-anak atau dewasa. Hasil penelitian ini menunjukan bahwa usia terbanyak yang menderita skabies yaitu pada kelompok usia 20-59 tahun sebanyak 128 kasus (49\%), dan jenis kelamin terbanyak yang menderita skabies yaitu laki-laki sebanyak 163 kasus (62,5\%).
\end{abstract}

Kata Kunci : Skabies, Prevalensi, Karakteristik

\begin{abstract}
Scabies is a skin disease caused by infestation and sensitization to Sarcoptes scabiei var hominis. Scabies characterized by night itching, affecting a group of people, with a predilection spot in the skin folds that are thin, warm, and moist. Clinical symptoms can be seen polymorphy spread throughout the body. Scabies disease can be prevented by educating patients about scabies which are: disease course, transmission, how to eradicate scabies mites, maintaining personal hygiene, and procedures for applying drugs. Objective: To determine the prevalence of the incidence of scabies and the factors that influence the incidence of scabies based on age and sex at Pertamina Bintang Amin Hospital for January 2, 2016 - December 31, 2018. The type of research used in this research is a descriptive retrospective study by looking at the medical records of scabies patients at the Polyclinic of Skin and Venereal Diseases at Pertamina Bintang Amin Hospital, Bandar Lampung, 2 January 2016-31 December 2018. In this study, the results of the prevalence of scabies were 261 cases (9\%) of 2924 patients with skin and venereal diseases for the period of January 2, 2016-31 December 2018 with the highest prevalence, namely in 2018 as many as 108 cases (11\%) of 963 patients with skin and venereal diseases. Scabies can occur in women or men and children or adults. The results of this study indicate that most people who suffer from scabies are in the age group of 20-59 years as many as 128 cases (49\%), and the most sexes suffer from scabies. Scabies, namely male, as many as 163 cases $(62.5 \%)$.
\end{abstract}

Keywords: Scabies, Prevalence, Characteristics

Author Korespondensi: Retno Oktavia, Universitas Malahayati, retnookta2610@gmail.com, 082280122921 


\section{PENDAHULUAN}

Skabies adalah penyakit kulit yang disebabkan oleh infestasi dan sensitisasi terhadap Sarcoptes scabiel var, hominis, dan produknya. Di tandai gatal malam hari, mengenai sekelompok orang, dengan tempat predileksi di lipatan kulit yang tipis, hangat, dan lembab. Gejala klinis dapat terlihat polimorfi tersebar diseluruh badan. ${ }^{1}$

Tungau ini adalah arthropoda yang termasuk dalam Phyllum Acarina, Kelas Arachnida, Ordo Astigmata, dan Famili Sarcoptidae. ${ }^{2}$ Tungau berbentuk seperti mutiara, tembus cahaya, putih, tanpa mata, dan berbentuk lonjong dengan empat pasang kaki pendek gemuk. Tungau betina dewasa berukuran $0,4 \times 0,3 \mathrm{~mm}$ dengan tungau jantan sedikit lebih kecil-sedikit terlalu kecil untuk dilihat dengan mata telanjang. Kutu skabies mampu hidup selama 3 hari lamanya dari inangnya dalam tabung reaksi yang steril, dan selama 7 hari jika ditempatkan di tempat minyak mineral. ${ }^{3}$

Skabies adalah kondisi dermatologis yang umum, memengaruhi lebih dari 130 juta orang setiap saat. Ini adalah penyakit terabaikan yang disebabkan oleh tungau Sarcoptes scabiei. Skabies sering menyebabkan rasa gatal yang parah, dan pada beberapa pasien, termasuk mereka yang memiliki kekebalan tubuh yang lemah, dapat berkembang menjadi "skabies berkerak". ${ }^{4}$

Penyakit ini dulu dikenal sebagai gatal 7 tahun, yaitu penyakit kulit menular yang menyerang manusia dan binatang. Dalam klasifikasi World Health Organization (WHO), skabies dikelompokkan sebagai water-related diseases. Penyebabnya adalah Sarcoptes scabiei, yaitu kutu parasit yang mampu menggali terowongan di kulit dan menyebabkan rasa gatal. ${ }^{1}$ Ini adalah masalah kesehatan yang signifikan di banyak negara berkembang dan dinyatakan sebagai penyakit kulit yang terabaikan oleh organisasi kesehatan dunia. ${ }^{2}$

Skabies mengenai keluarga dan masyarakat di seluruh dunia. Penyakit ini paling sering pada anak, dewasa muda, dan usia lanjut. Faktor yang menyebabkan penyebaran skabies mencakup: kemiskinan dan lingkungan yang padat, rumah peristirahatan, rumah sakit, penjara, kemah pengungsi, orang dengan defisiensi imun atau supresi imun, rendahnya angka identifikasi dan terapi skabies yang benar. ${ }^{5}$ Umumnya skabies menyerang individu yang hidup berkelompok seperti di asrama, lembaga pemasyarakatan, perkampungan padat, rumah jompo dan pesantren. ${ }^{6}$

Anak-anak lebih mudah terserang Skabies karena daya tahan tubuh yang lebih rendah dari orang dewasa, kurangnya kebersihan, dan lebih seringnya mereka bermain bersama anak-anak lain dengan kontak yang erat. Skabies juga mudah menginfestasi orang usia lanjut karena imunitas yang menurun dan perubahan fisiologi kulit menua. $^{7}$

Skabies dapat menginfestasi laki-laki maupun perempuan, tetapi laki-laki lebih sering menderita skabies. Hal tersebut disebabkan lakilaki kurang memerhatikan kebersihan diri dibandingkan perempuan. ${ }^{7}$

Jika merupakan episode pertama, gatal muncul 4-6 minggu setelah penularan kutu. Pada infestasi selanjutnya, gatal dapat muncul dalam beberapa jam. Gatal biasanya lebih hebat pada malam hari, mengganggu tidur. Penyakit mengenai badan dan ekstremitas, tidak mengenai kulit kepala (kecuali pada bayi dan pada skabies berkrusta). Gatal ringan atau tidak ada pada sebagian pasien dengan skabies berkrusta. Gatal dapat menetap beberapa minggu setelah pengobatan yang berhasil mematikan kutu. $^{5}$

Lesi terowongan pada skabies terlihat sebagai alur-alur ireguler $0,5-1,5 \mathrm{~cm}$ di sela jari tangan, telapak tangan, dan pergelangan tangan. Lesi juga dapat ditemukan di siku, puting payudara, ketiak, bokong, penis, instep, dan tumit. Pemeriksaan dermatoskopik atau mikroskopik isi lesi terowongan mungkin memperlihatkan tungau, telur, atau tinja kutu (skibala). Sampai minggu setelah infestasi awal. ${ }^{5}$

Cara penularan (transmisi) skabies yaitu kontak langsung (kontak kulit dengan kulit), misalnya berjabat tangan, tidur bersama, dan hubungan seksual. Kontak tak langsung (melalui benda), misalnya pakaian, handuk, sprei, bantal, dan lain-lain. Penularannya biasanya oleh 
Sarcoptes scabiei betina yang sudah dibuahi atau kadang-kadang oleh bentuk larva. Dikenal juga Sarcoptes scabiei var.animalis yang kadang-kadang dapat menulari manusia, terutama pada mereka yang banyak memelihara binatang peliharaan, misalnya anjing. ${ }^{1}$

Dalam upaya preventif, perlu dilakukan edukasi pada pasien tentang penyakit skabies, perjalanan penyakit, penularan, cara eradikasi tungau skabies, menjaga higiene pribadi, dan tata cara pengolesan obat. Rasa gatal terkadang tetap berlangsung walaupun kulit sudah bersih. Pengobatan dilakukan pada orang serumah dan orang di sekitar pasien yang berhubungan erat. ${ }^{1}$

Prevalensi skabies berkisar antara $0,2 \%$ hingga $71 \%$. Skabies merupakan penyakit endemik di banyak negara tropis, dengan perkiraan prevalensi rata-rata $5-10 \%$ pada anakanak. ${ }^{8}$ Skabies umumnya terjadi pada usia 12-14 tahun dan lebih sering menginfestasi anak lakilaki daripada perempuan. Hal ini dikarenakan perempuan lebih memperhatikan kebersihan diri. $^{9}$

Penyakit skabies dapat menurunkan kualitas hidup pasien. Sebanyak $72 \%$ pasien dewasa dengan skabies merasa malu karena penyakitnya tersebut. Tidak jauh berbeda dengan hasil survey di Tiongkok yang menunjukan $78 \%$ pasien skabies mengalami penurunan kualitas hidup. ${ }^{10}$

Di Indonesia, skabies merupakan salah satu penyakit kulit tersering di puskesmas. Pada tahun 2008, prevalensi skabies di seluruh puskesmas di Indonesia adalah 5,6-12,9\%. ${ }^{11}$ Berdasarkan data dari Dinas Kesehatan Provinsi Lampung tahun 2011, jumlah kasus baru pada penyakit skabies berjumlah 1135 orang, dan tahun 2012 mengalami peningkatan lebih dari dua kali lipat menjadi 2941 orang. ${ }^{12}$ Prevalensi skabies di Indonesia menurut Depkes RI data dari puskesmas seluruh Indonesia pada tahun 2015, angka kejadian skabies adalah 5,6$12,95 \%$. Di Indonesia penyakit skabies menduduki urutan ketiga dari dua belas penyakit kulit tersering, saat ini angka kejadian skabies meningkat lebih tinggi dari 20 tahun yang lalu, dan banyak ditemukan pada panti asuhan, asrama, pondok pesantren, penjara dan rumah sakit. ${ }^{13}$
Kejadian skabies masih sering terjadi dikalangan masyarakat terutama pada anakanak, dewasa muda dan orang tua.dengan berbagai karakteristik yang dapat dijumpai. Hal itulah yang menarik minat peneliti untuk melakukan penelitian mengenai skabies di Poliklinik RS Pertamina Bintang Amin periode 2 januari 2016-31 Desember 2018.

\section{METODOLOGI}

Dalam penelitian ini, peneliti menggunakan jenis penelitian studi retrospektif deskriptif. Penelitian ini dilakukan pada bulan Desember tahun 2020 sampai dengan selesai di Poliklinik Penyakit Kulit dan Kelamin Rumah Sakit Pertamina Bintang Amin Bandar Lampung. Dalam penelitian ini peneliti menggunakan teknik Purposive Sampling yaitu pengambilan sampel secara sengaja, didasarkan atas ciri-ciri tertentu yang mempunyai hubungan dengan kriteria inklusi dan mewakili populasi.

\section{HASIL DAN PEMBAHASAN}

Pada penelitian ini didapatkan seluruh total sampel sebanyak 261 pasien yang memenuhi kriteria inklusi dan ekslusi. Data yang diperoleh yaitu sebagai berikut:

Tabel 1. Prevalensi pasien skabies dari seluruh pasien penyakit kulit dan kelamin

\begin{tabular}{cccc}
\hline Tahun & $\begin{array}{c}\text { Penderita } \\
\text { Skabies }\end{array}$ & $\begin{array}{c}\text { Pasien } \\
\text { Kulit dan } \\
\text { Kelamin }\end{array}$ & Presentase \\
\hline 2016 & 69 & 1047 & $6,6 \%$ \\
\hline 2017 & 84 & 914 & $9 \%$ \\
\hline 2018 & 108 & 963 & $11 \%$ \\
\hline prevalensi & $\mathbf{2 6 1}$ & $\mathbf{2 9 2 4}$ & $\mathbf{9 \%}$ \\
\hline
\end{tabular}

Pada tabel diatas dapat dilihat bahwa berdasarkan dari 261 pasien skabies yang tercatat di Poliklinik Rumah Sakit Pertamina Bintang Amin periode 02 Januari 2016-31 Desember 2018, didapatkan hasil prevalensi pasien skabies adalah 9\% dari 2924 pasien di Poliklinik penyakit kulit dan kelamin Rumah Sakit Pertamina Bintang Amin. 
Pada tahun 2016 didapatkan sebanyak 69 $(6,6 \%)$ pasien skabies dari 1047 pasien penyakit kulit dan kelamin. Pada tahun 2017 didapatkan sebanyak $84(9 \%)$ pasien skabies dari 914 pasien penyakit kulit dan kelamin. Pada tahun 2018 didapatkan sebanyak 108 (11\%) pasien skabies dari 963 pasien penyakit kulit dan kelamin. Dari tahun 2016-2018 didapatkan sebanyak 261 (9\%) pasien skabies dari 2924 pasien penyakit kulit dan kelamin.

Tabel 2. Distribusi Frekuensi Pasien Skabies Berdasarkan Usia

\begin{tabular}{clcc}
\hline No & \multicolumn{1}{c}{ Usia } & Jumlah & $\mathbf{\%}$ \\
\hline 1. & $0-4$ tahun & 11 & 4,2 \\
2. & 5-9 tahun & 24 & 9,2 \\
3. & 10-19 tahun & 64 & 24,5 \\
4. & 20-59 tahun & 128 & 49 \\
5. & $\geq 60$ tahun & 34 & 13 \\
\hline & Total & $\mathbf{2 6 1}$ & $\mathbf{1 0 0}$ \\
\hline
\end{tabular}

Pada tabel diatas dapat dilihat bahwa distribusi frekuensi penderita penyakit skabies menurut usia, didapatkan 11 pasien $(4,2 \%)$ pada kelompok usia 0-4 tahun kemudian sebanyak 24 pasien $(9,2 \%)$ pada kelompok usia 5-9 tahun, 64 pasien $(24,5 \%)$ pada kelompok usia 10-19 tahun, 128 pasien (49\%) pada kelompok usia 20-59 tahun, dan 34 pasien (13\%) pada kelompok usia lebih dari sama dengan 60 tahun.

Tabel 3. Distribusi Frekuensi Pasien Skabies Berdasarkan Jenis Kelamin

\begin{tabular}{clcc}
\hline No & $\begin{array}{c}\text { Jenis } \\
\text { Kelamin }\end{array}$ & Jumlah & \% \\
\hline 1. & Laki-laki & 163 & 62,5 \\
2. & Perempuan & 98 & 37,5 \\
\hline & Total & $\mathbf{2 6 1}$ & $\mathbf{1 0 0}$ \\
\hline
\end{tabular}

Tabel di atas memperlihatkan distribusi insidensi penderita penyakit skabies menurut jenis kelamin, dimana 163 pasien $(62,5 \%)$ berjenis kelamin laki-laki dan 98 pasien $(37,5 \%)$ berjenis kelamin perempuan.
Berdasarkan hasil penelitian yang telah dilakukan, menunjukan hasil bahwa terjadi kenaikan kasus skabies yang signifikan setiap tahunnya. Kasus skabies tertinggi terjadi pada tahun 2018 sebanyak 108 pasien (11\%) dari 963 pasien penyakit kulit dan kelamin. kemudian kasus skabies terendah yaitu pada tahun 2016 sebanyak 69 pasien $(6,6 \%)$ dari 1047 pasien penyakit kulit dan kelamin.

Dari hasil penelitian sebelumya oleh Widasmara pada tahun 2020 di Rumah Sakit Umum Daerah dr. Saiful Anwar Malang tahun 2014-2018 prevalensi kasus skabies mengalami presentase yang naik-turun setiap tahunnya dengan presentase tertinggi pada tahun 2014 $(8,7 \%)$ dan terendah pada tahun $2015(6,3 \%) .{ }^{14}$

Hasil penelitian ini sesuai dengan yang dikatakan oleh Widiastini dan Saftarina pada tahun 2020 yaitu berdasarkan data dari Dinas Kesehatan Provinsi Lampung tahun 2011, jumlah kasus baru pada penyakit skabies berjumlah 1135 orang, dan tahun 2012 mengalami peningkatan lebih dari dua kali lipat menjadi 2941 orang. ${ }^{15}$

Faktor yang berperan pada tingginya prevalensi skabies adalah kemiskinan, kepadatan penghuni rumah, tingkat pendidikan rendah, keterbatasan air bersih, dan perilaku kebersihan yang buruk. Kepadatan penghuni rumah merupakan faktor risiko yang paling dominan dibandingkan faktor risiko skabies lainnya. Tingginya kepadatan penghuni disertai interaksi dan kontak fisik yang erat memudahkan penularan skabies. ${ }^{15}$

Negara Indonesia merupakan wilayah beriklim tropis dengan jumlah penduduk terbesar ke-4 di dunia, sehingga peningkatan jumlah penduduk bisa lebih cepat membuat lingkungan keluarga atau tempat tinggal menjadi padat dan lembab. Kemudian ditempat yang banyak di datangi orang seperti rumah sakit, penjara, dan lain-lain membuat kontak antar kulit ke kulit dan pemakaian barang bersamasama menjadi lebih sering. Ditambah dengan kemungkinan tingkat pendidikan rendah membuat individu kurang sadar akan kebersihan pribadi dan peran kebersihan yang buruk dalam penyebaran penyakit menular. ${ }^{14}$ 
Pada penelitian ini menunjukkan bahwa distribusi frekuensi karakteristik sampel skabies terbanyak berdasarkan usia yaitu pada kelompok usia 20-59 tahun yaitu sebanyak 128 pasien $(49 \%)$.

Hasil penelitian ini tidak sejalan dengan penelitian yang dilakukan oleh Sinaga pada tahun 2020 di RS UKI (Universitas Kristen Indonesia) Jakarta dengan konfirmasi hasil pemeriksaan Laboratorium Parasitologi FK UKI periode Januari 2014-Agustus 2019 dengan jumlah sampel sebanyak 30 orang pasien skabies di Rumah Sakit UKI, hasil yang didapatkan yaitu 53,3\% anak-anak dan remaja. ${ }^{16}$

Pada dasarnya, pada kelompok usia 20-59 tahun harusnya sudah mengerti tentang menjaga higienisitas diri dan lingkungannya. Karena dengan bertambahnya umur seseorang akan terjadi perubahan pada aspek fisik dan psikologis (mental). Pertumbuhan pada fisik secara garis besar ada 4 kategori yaitu perubahan ukuran, perubahan proporsi, hilangnya ciri-ciri lama, dan timbulnya ciri-ciri baru. Pada aspek psikologis atau mental taraf berfikir seseorang semakin matang dan dewasa. Hal ini kemungkinan disebabkan karena pada kelompok usia 20-59 tahun tertular dari anak atau saudara yang baru pulang dari suatu tempat yang terdapat banyak kasus skabies, contohnya seperti pondok pesantren, penjara, asrama, dan lain-lain. Sehingga infestasi sulit dihindari karena tinggal dekat dengan penderita yang memiliki gejala atau tidak memiliki gejala dari penyakit skabies. Atau bisa juga mereka yang menderita skabies tinggal di daerah pemukiman padat penduduk sehingga penyebaran skabies menjadi lebih mudah. ${ }^{17}$

Pada penelitian ini didapatkan hasil distribusi penderita skabies berdasarkan jenis kelamin ditemukan bahwa jenis kelamin lakilaki lebih banyak menderita skabies yaitu 163 pasien $(62,5 \%)$ dibandingkan dengan perempuan yang jumlahnya 98 pasien $(37,5 \%)$.

Hasil ini serupa dengan penelitian yang dilakukan oleh Bancin et al pada tahun 2020 di Poli Kulit dan Kelamin RSUD Meuraksa Kota Banda Aceh periode tahun 2016- 2018 dengan jumlah sampel sebanyak 395 responden, diketahui bahwa mayoritas responden yang banyak terkena penyakit kulit skabies adalah berjenis kelamin laki-laki yaitu sebanyak 276 responden $(69.9 \%) .{ }^{18}$

Kemudian hasil penelitian ini juga sejalan dengan penelitian yang dilakukan oleh Sinaga pada tahun 2020 di RS UKI (Universitas Kristen Indonesia) Jakarta dengan konfirmasi hasil pemeriksaan Laboratorium Parasitologi FK UKI periode Januari 2014-Agustus 2019 dengan jumlah sampel sebanyak 30 orang pasien skabies di Rumah Sakit UKI, hasil yang didapatkan yaitu $63,3 \%$ berjenis kelamin laki-laki. ${ }^{16}$

Hasil penelitian ini menunjukkan prevalensi skabies berhubungan dengan jenis kelamin, yaitu penyakit skabies lebih banyak pada jenis kelamin laki-laki yang berarti laki-laki lebih berisiko terinfestasi skabies dibandingkan perempuan. Pada penelitian ini didapatkan lebih banyak laki-laki yang terkena skabies, kemungkinan dapat disebabkan karena aktivitas laki-laki lebih banyak dibandingkan perempuan. Hal tersebut juga disebabkan karena laki-laki kurang memerhatikan kebersihan diri dibandingkan perempuan yang tentunya kebersihan berpengaruh terhadap kejadian skabies. ${ }^{1}$

Pada dasarnya skabies mengenai keluarga dan masyarakat di seluruh dunia. Namun yang perlu diwaspadai adalah pengaruh lingkungan yang padat, tempat umum yang sering dikunjungi banyak orang, penggunaan barang secara bergantian, kemudian faktor higienisitas yang buruk dapat meningkatkan risiko tertularnya penyakit skabies. ${ }^{14}$

\section{KESIMPULAN DAN SARAN}

Berdasarkan penelitian yang telah dilakukan mengenai karakteristik pasien skabies berdasarkan faktor usia dan jenis kelamin di Rumah Sakit Pertamina Bintang Amin periode 02 Januari 2016-31 Desember 2018, dapat diambil kesimpulan bahwa:

1. Berdasarkan prevalensi, prevalensi pasien skabies tertinggi yaitu pada tahun 2018 sebanyak 108 pasien skabies (11\%) dari 963 pasien penyakit kulit dan kelamin. prevalensi terendah pada tahun 2016 yaitu sebanyak 69 
pasien skabies $(6,6 \%)$ dari 1047 pasien penyakit kulit dan kelamin.

2. Berdasarkan usia pasien, penderita skabies paling banyak ditemukan pada usia 20-59 tahun yaitu sebanyak 128 orang (49\%). Dan paling sedikit pada kelompok usia 0-4 tahun yaitu sebanyak 11 orang $(4,2 \%)$.

3. Berdasarkan jenis kelamin pasien, penderita skabies paling banyak ditemukan pada jenis kelamin laki-laki yaitu sebanyak 163 orang (62,5\%). Dan paling sedikit ditemukan pada wanita yaitu sebanyak 98 orang $(37,5 \%)$.

\section{SARAN}

Berdasarkan hasil dari penelitian ini, ada beberapa saran dari peneliti yang bisa disampaikan, diantaranya:

1. Tempat pelayanan kesehatan diharapkan dapat mengadakan kegiatan promosi kesehatan tentang edukasi dan pencegahan terhadap penyakit kulit menular khususnya skabies. Terutama dalam hal menjaga kebersihan diri, kebersihan rumah dan lingkungan tempat tinggal. Sehingga terciptanya kesadaran diri untuk hidup sehat dengan lingkungan yang sehat.

2. Hasil penelitian ini dapat dijadikan sebagai referensi tambahan dan dapat dilakukan penelitian yang lebih lanjut lagi dengan menggunakan sampel serta lokasi yang lebih besar dan berbeda sehingga dapat lebih mewakili populasi di daerah tersebut.

3. Hasil penelitian ini dapat dijadikan suatu informasi kepada masyarakat mengenai skabies. Maka dari itu bagi tenaga kesehatan sebaiknya mengisi data rekam medis dengan lengkap lagi sehingga dapat menjadi evaluasi kedepannya demi menghadapi permasalahan kesehatan yang akan datang.

\section{UCAPAN TERIMAKASIH}

Ucapan terimakasih kepada dr. Sri Maria Puji Lestari, M.PD, Ked selaku Kepala Prodi Pendidikan Dokter Universitas Malahayati Bandar Lampung, Dosen Pembimbing, serta semua pihak yang telah banyak memberikan bantuan dalam penyelesaian penelitian ini.

\section{REFERENSI}

1. Menaldi, S. L. SW. (Eds.). Ilmu penyakit kulit dan kelamin (5 vols.). Jakarta: Fakultas Kedokteran Universitas Indonesia; 2018.

2. Gilson, R.L., Crane, J.S. Scabies (Sarcoptes Scabiei). $2020 \quad$ [09 Oktober 2020]. https://www.ncbi.nlm.nih.gov/books/NBK544306 l.

3. Goldsmith, L.A. (Eds). Fitzpatrick's dermatology in general medicine (8 vols). New York: Mc Grow Hill Companies; 2012.

4. Linden, N.V.D., Gool, K.V., Gardner, K., dkk. A Systematic Review Of Scabies Transmission Models And Data To Evaluate The CostEffectiveness Of Scabies Interventions. 2019 [23 November 2020]. http://doi.org/10.1371/journal.pntd.0 007182.

5. Oakley, M. Dermatologi Lengkap: Atlas Dan Rangkuman Klinis. Jakarta: EGC; 2019.

6. Juliansyah, E., Minartami, L. A. Jenis Kelamin, Personal Hygiene, dan Sanitasi Lingkungan Dengan Kejadian Penyakit Scabies Pada Santri Di Pondok Pesantren Darul Ma'arif Kabupaten Sintang. Jumantik. 2017; 1(4): 1-11.

7. Sungkar, S. Skabies: Etiologi, Patogenesis, Pengobatan, Pemberantasan, dan Pencegahan. Jakarta: Fakultas Kedokteran Universitas Indonesia; 2016.

8. WHO. Scabies. 2020 [06 Oktober 2020] https://www.who.int/news-room/factsheets/detail/scabies.

9. Merti, L.G.I.A., Mutiara, H., Suwandi, J.F., Ayu, P.R. Hubungan skabies dengan prestasi belajar pada santri pondok pesantren di Bandar Lampung. Medula. 2019; 2(8): 76-81.

10. Shobirin, M.Y., Mayasari, D. Penatalaksanaan skabies pada anak perempuan usia satu tahun dengan pendekatan kedokteran keluarga. J Medula Unila. 2017; 3(7): 50-56.

11. Kurniawan, M., Ling, M.S.S., Franklind. Diagnosis dan terapi skabies. Cdkjournal. 2020; 2(47):104-107.

12. Widiastini, A.A., Saftarina, F. 2020. Penatalaksanaan skabies infeksi sekunder pada anak usia sekolah dengan pendekatan kedokteran keluarga di Puskesmas Natar. Majority. 2020; $1(9): 1-8$.

13. Alhidayati, Syukaisih, Amalia, R., Sukma, I. Faktor yang berhubungan dengan penyakit skabies pada siswa asrama di SMKN Pertanian Terpadu Provinsi Riau. Jurnal Ilmiah. 2020; 2(15): 105-113. 
14. Widasmara, D. Konsep Baru Skabies. Malang: UB Pess; 2020.

15. Rahmatia, N., Ernawati, T. Penatalaksanaan Skabies Melalui Pendekatan Kedokteran Keluarga di Wilayah Kerja Puskesmas Satelit. Majority. 2020; 1(9): 1-8.

16. Sinaga, B.J. Karakteristik Pasien Skabies di RS UKI Dengan Konfirmasi Hasil Pemeriksaan Laboratorium Parasitologi FK UKI Periode Januari 2014-Agustus 2019. Skripsi. Program gelar sarjana kedokteran. Jakarta; 2020.

17. Imarta, A. G., Wulan, A. J., Saftarina, F. FaktorFaktor Yang Berhubungan Dengan Kejadian Skabies di Pondok Pesantren Jabal An-nur AlIslami Kecamatan Teluk Betung Barat Kota Bandar Lampung. Medula. 2017; 5(7): 1-8.

18. Bancin, M.M., Martafari, C.A., Kurniawan, R. 2020. Prevalensi penderita skabies di Poli Kulit dan Kelamin RSUD Meuraxa kota Banda Aceh periode tahun 2016-2018. Kandidat: Jurnal Riset dan Inovasi Pendidikan. 2020; 1(2): 20-28. 